\title{
The effects of conjugated linoleic acid (CLA) and canola oil on the fatty acid composition and quality of eggs from laying hens
}

\author{
R. Aydin \\ Department of Animal Science, Kahramanmaras Sutcu Imam University, 46060 Kahramanmaras-Turkey
}

\begin{abstract}
Dietary conjugated linoleic acid (CLA) causes adverse effects on quality of eggs by modifying the fatty acid composition of the yolk. Supplementing oils prevent CLA-induced changes, but cause a decrease in the level of egg CLA. The objective of the study was to investigate the incorporation of CLA into the egg and its effect on the fatty acid metabolism when laying hens were fed diets containing different levels of canola oil. Hens (15 per group) were assigned to six groups and were fed for 50 days diets containing $0.5 \%$ canola oil (Group A), 0.5\% CLA (Group B), 0.5\% CLA plus 1.25\% canola oil (Group C), 0.5\% CLA plus $2.5 \%$ canola oil (Group D), $0.5 \%$ CLA plus 5\% canola oil (Group E) or $0.5 \%$ CLA plus 10\% canola oil. Eggs were collected daily. Three eggs per group were used for fatty acid analysis. Eggs laid on days 1 to11 were stored at $4{ }^{\circ} \mathrm{C}$ or room temperature for 30 days, and were separated into yolk and albumen for $\mathrm{pH}$ analyses. Yolk from Group B had increased concentrations of C16:0 and C18:0 and decreased concentrations of C18:1(n-9) compared to Group A. Adding 5\% or 10\% canola oil (Groups E or F) to the diet prevented an increase in C16:0 and C18:0 and a decrease in C18:1(n-9) concentrations. Relative amounts of CLA in eggs from Groups A, B, C, D, E and F were $0,2.38,2.33,1.68,1.36$, and $1.17 \%$, respectively. The concentrations of C18:3(n-3) in Groups A, B, C, D, E and F were 0.23, 0.25, 0.61, 0.70, 1.23 and 1.58\%, respectively. The ratios of UFA/SFA in the eggs from Groups $\mathrm{B}, \mathrm{C}$ and $\mathrm{D}$ decreased. When the eggs were stored at $4{ }^{\circ} \mathrm{C}$, the yolk from Groups $\mathrm{B}, \mathrm{C}$ and $\mathrm{D}$ had higher $\mathrm{pH}$ values than the other treatments, while the albumen $\mathrm{pH}$ of eggs from Groups B, C and D were lower. However, when eggs were stored at room temperature, no abnormal pH changes were observed in the yolk or albumen. This study suggested that adding a certain level of canola oil rich in n-3 fatty acids restored the level of egg yolk SFA to UFA, prevented CLA-induced abnormal changes in egg quality and thus led to a higher level of C18:3(n-3) and CLA in the egg.
\end{abstract}

Keywords: Conjugated linoleic acid, unsaturated fatty acids, egg yolk and albumen $\mathrm{pH}$, chickens E-mail: rahimaydin@ksu.edu.tr

\section{Introduction}

Conjugated linoleic acid (CLA) is a term used for a group of positional and geometrical isomers of linoleic acid, an essential fatty acid for human and animals. It has received considerable attention because of its many biological properties, including an anticarcinogenic effect (Ip et al., 1994; Banni \& Martin, 1998; Corl et al., 2003), a fat reducing effect (Blankson et al., 2000) and immune-enhancing activity (Cook et al., 1993).

In nature, dairy products and meat from ruminants are the main sources of CLA in human diets (Chin et al., 1992) and contain $2.9-5.6 \mathrm{mg} \mathrm{CLA} / \mathrm{g}$ fat. It has been estimated that in order to obtain the health benefits mentioned, a $70 \mathrm{~kg}$ human would have to consume about 1.5 - $3 \mathrm{~g}$ of CLA daily (Decker, 1995). However, the concentrations of CLA found in natural products are not high enough to achieve the beneficial effects of CLA. For this reason there is a considerable interest in enriching products from animals such as chicken eggs and dairy products with CLA (Franklin et al., 1999; Jones et al., 2000; Raes et al., 2002).

Chicken eggs normally contain little or no CLA. Previous work has demonstrated that a chicken egg could be enriched by as high as $11 \%$ with CLA by feeding a diet supplemented with 5\% CLA (Chamruspollert \& Sell, 1999). Another study showed that a diet containing 5\% CLA could enrich the chicken egg by about 15\% CLA (Du et al., 1999). Du et al. (1999) reported that a $60 \mathrm{~g}$ egg from a hen fed a diet containing 5\% CLA would provide over one-third of the daily recommended requirement of $3 \mathrm{~g}$ CLA of an adult human. Since the incorporation of CLA into egg lipids is dose-dependent, it is possible to enrich an egg to contain a desirable level of CLA (Aydin \& Cook, 2004). However, it has been reported that the 
adding of CLA to a low-fat diet can cause undesirable changes (i.e. discoloration of egg yolk and albumen and abnormal $\mathrm{pH}$ changes) to the quality of eggs stored at $4{ }^{\circ} \mathrm{C}$ (Aydin et al., 2001). Feeding CLA to chicken can modify the levels of mono-unsaturated fatty acids (MUFA) and saturated fatty acids (SFA) in the egg yolk possibly by inhibiting the stearoyl-CoA desaturase enzyme (Park et al., 2000). Therefore, CLA in a low-fat diet caused undesirable effects in the colour and pH of egg albumen and yolk (Aydin et al., 2001). Those undesirable effects were prevented by adding $10 \%$ olive oil to a diet containing $0.5 \%$ CLA (Aydin et al., 2001). Another study showed that $9.5 \%$ animal fat (tallow) prevented CLA-related abnormal changes in egg quality (Aydin \& Cook, 2005). However, while adding high levels of oils could restore the levels of fatty acids in egg yolk, they also caused a decrease in the concentrations of the main isomers (c-9, t-11 and t-10, c12 CLA isomers) and total CLA, which is undesired (Aydin et al., 2001; Aydin \& Cook, 2005). Hence, the objective of this study was to determine the level of canola oil as an additional oil (rich in C18:3, n-3, an essential fatty acid for human and animals) to alleviate the adverse effects of dietary CLA on egg characteristics and to obtain an egg containing an optimum concentration of CLA.

\section{Material and Methods}

Table 1 Feed ingredients of the experimental diets containing different levels of conjugated linoleic acid (CLA) and canola oil

\begin{tabular}{|c|c|c|c|c|c|c|}
\hline \multirow{2}{*}{ Ingredient } & \multicolumn{6}{|c|}{ Dietary treatments ${ }^{1}\left(\mathrm{~g} / 100 \mathrm{~g}\right.$ diet $\left.^{2}\right)$} \\
\hline & Group A & Group B & Group C & Group D & Group E & Group F \\
\hline Maize grain & 68.1 & 68.1 & 63.38 & 59.67 & 48.67 & 26.64 \\
\hline Wheat middlings & 2.40 & 2.40 & 3.0 & 4.29 & 13.10 & 30.74 \\
\hline Maize gluten feed & 0 & 0 & 0 & 2.22 & 3.48 & 6.02 \\
\hline Soyabean meal (44\%) & 17.92 & 17.92 & 20.66 & 19.69 & 18.20 & 15.21 \\
\hline Calcium carbonate & 8.62 & 8.62 & 8.42 & 8.46 & 8.50 & 8.59 \\
\hline Dicalcium phosphate & 0.88 & 0.88 & 1.22 & 1.10 & 0.98 & 0.72 \\
\hline Lysine & 0.01 & 0.01 & 0 & 0 & 0 & 0 \\
\hline Methionine & 0.07 & 0.07 & 0.07 & 0.07 & 0.07 & 0.08 \\
\hline $\mathrm{CLA}^{3}$ & 0 & 0.5 & 0.5 & 0.5 & 0.5 & 0.5 \\
\hline Canola oil & 0.5 & 0 & 1.25 & 2.5 & 5 & 10 \\
\hline Salt & 0.5 & 0.5 & 0.5 & 0.5 & 0.5 & 0.5 \\
\hline Premix $^{4}$ & 1.0 & 1.0 & 1.0 & 1.0 & 1.0 & 1.0 \\
\hline $\begin{array}{l}{ }^{1} \text { Treatments: Group A } \\
0.5 \% \text { CLA plus } 2.5 \% \text { c } \\
{ }^{2} \text { Diets were calculated } \\
{ }^{3} \text { The source of CLA co } \\
1.11 \% \text { c- } 9, \text { c- } 11 ; 1.57 \% \\
2.39 \% \text { stearate, } 13.77 \% \\
{ }^{4} \text { Supplied per kg of die } \\
\text { mg; calcium panthothen } \\
\text { mg; manganese oxide - }\end{array}$ & $\begin{array}{l}\text { canola oil; } \\
\text { il; Group E } \\
\text { ain } 150 \text { g c1 } \\
\text { 80\% CLA } \\
\text { - } 12 ; 0.91 \% \\
0.81 \% \text { lin } \\
\text { in A - } 10,0 \\
0 \text { mg; niaci } \\
\text { copper - } 7\end{array}$ & $\begin{array}{l}\text { up B }-0.5 \% \\
5 \% \text { CLA pl } \\
\text { protein } / \mathrm{kg} \\
\text { consisted o } \\
\text { t- } 11 \text { and t- } \\
\text { and } 1.75 \% \\
\mathrm{U} \text {; vitamin } \\
2 \mathrm{mg} \text {; choli } \\
\text { iron }-160\end{array}$ & $\begin{array}{l}\text { A; Group } \\
\% \text { canola o } \\
11.7 \text { MJ m } \\
.33 \% \text { c-9, } \\
-12 \text {. Other } \\
\text { known } \\
9790 \mathrm{IU} ; \mathrm{v} \\
840 \mathrm{mg} \text {; b } \\
\text { selenium - }\end{array}$ & $\begin{array}{l}5 \% \text { CLA p } \\
\text { Group F - } \\
\text { lisable en } \\
\text { and t-9, c-1 } \\
\text { y acids in } \\
\text { in E - } 121 \\
\text { - 30 } \mu \text { g; th } \\
\text { mg; vitami }\end{array}$ & $\begin{array}{l}.25 \% \text { cano } \\
\text { 6 CLA plus } \\
\mathrm{kg} \\
5.72 \% \mathrm{t}-10 \\
-80 \text { were } 6 . \\
\mathrm{B}_{12}-20 \mu \mathrm{g} \\
\mathrm{ee}-4 \mathrm{mg} ; \\
-2 \mathrm{mg} ; \mathrm{py}\end{array}$ & $\begin{array}{l}\text {; Group D - } \\
\text { canola oil } \\
\text { palmitate, } \\
\text { flavin - } 4.4 \\
\text { ulphate - } 60 \\
\text { ine - } 3 \text { mg }\end{array}$ \\
\hline
\end{tabular}


Ninety Single Comb White Leghorn laying hens were assigned to six groups (15 per treatment) and were housed in individual cages with a light regimen of $16 \mathrm{~h}$ light : $8 \mathrm{~h}$ darkness. They were fed for 50 days one of the following six experimental diets: Group A - containing 0.5\% canola oil; Group B - 0.5\% CLA; Group C - 1.25\% canola oil plus 0.5\% CLA; Group D - 2.5\% canola oil plus $0.5 \%$ CLA, Group E - 5\% canola oil plus $0.5 \%$ CLA or Group F - 10\% canola oil plus $0.5 \%$ CLA. The ingredient composition of the experimental diets and the fatty acid composition of the CLA-80 (Natural Lipids, Hovdebygda, Norway) are presented in Table 1. All diets contained $150 \mathrm{~g}$ crude protein $/ \mathrm{kg}$ and $11.7 \mathrm{MJ}$ metabolisable energy $/ \mathrm{kg}$.

Five whole eggs per group were collected daily on days 1 to 11 of the study for yolk and albumen $\mathrm{pH}$ measurements. The eggs from days 1 to 10 were stored at $4{ }^{\circ} \mathrm{C}$ and those from day 11 were stored at room temperature $\left(21-24{ }^{\circ} \mathrm{C}\right)$, for 30 days. Previous studies (Aydin et al., 2001) have shown that the cold storage conditions $\left(4^{\circ} \mathrm{C}\right)$ resulted in changes in the quality of eggs from CLA-fed hens. After the 30 days the eggs were broken and separated into yolks and albumen. Discoloration of the yolk and albumen were recorded. The albumen and yolk samples were then stirred with a glass rod for $\mathrm{pH}$ measurements [Fisher Scientific Accumet $\mathrm{pH}$ meter (910), Pittsburgh, PA].

Fatty acid analyses were carried out as described by Aydin et al. (2001). Briefly, fats from egg yolks (three eggs per group laid on day 10) were extracted with chloroform $/$ methanol $(2: 1, \mathrm{v} / \mathrm{v})$ (Folch et al., 1957). Fatty acid methyl esters (FAME) were prepared by reaction with $4 \% \mathrm{HCl}$ in methanol for $20 \mathrm{~min}$ at $60{ }^{\circ} \mathrm{C}$. The composition of the FAME was analyzed by gas chromatography (GC) (Hewlett-Packard 5890 series II) using a supercovax-10 fused silica capillary (60 m X $0.32 \mathrm{~mm}$ i.d., $0.25 \mu \mathrm{m}$ film thickness). Oven temperature was programmed from 50 to $200{ }^{\circ} \mathrm{C}$, increased $20^{\circ} \mathrm{C}$ per min., held for $50 \mathrm{~min}$, increased $10{ }^{\circ} \mathrm{C}$ per min to $230^{\circ} \mathrm{C}$, and held for 20 min. Heptadecanoic acid (C17:0) (Sigma Chemical Co., St Louis, MO) was included as an internal standard. The FAME were identified by comparison of retention times with methylated fatty acid standards (Sigma Chemical Co., St Louis, MO and Nu-Chek Prep., Elysian, MN) and expressed as percentage of total FAME (Chin et al., 1992).

Fatty acid levels in the egg yolk lipids were expressed as a percentage of total fatty acid methyl esters. To examine the effect of canola and CLA on the fatty acid composition of egg yolk lipids and $\mathrm{pH}$ values of yolk and albumen of eggs stored at $4{ }^{\circ} \mathrm{C}$ or room temperature, a general linear model (multivariate) was carried out. Mean values for the groups were compared using the Tukey multiple range test (SPSS software 10.0; Chicago, IL). Differences were considered significant at the level of $\mathrm{P}<0.05$.

\section{Results}

The addition of CLA to the low-fat diet (Group B) caused significant changes in the fatty acid composition of the yolk by increasing the concentration of SFA (mainly C14:0, C16:0, and C18:0) and decreasing the concentration of MUFA (mainly C18:1, n-9) (Table 2). The concentration of C16:1(n-7) of the yolk from Group B decreased $(\mathrm{P}<0.05)$ compared to Group A. However, adding canola oil to the diet (Groups C, D, E and F) did not prevent the decrease in the concentration of C16:1(n-7) compared to Group A. The ratio of $\mathrm{C} 16: 0$ to $\mathrm{C} 16: 1(\mathrm{n}-7)$ of the yolk was 5.8, 28.7, 37.6, 38.6, 48.9, and 64.3 in Groups A, B, C, $\mathrm{D}, \mathrm{E}$ and $\mathrm{F}$, respectively. The concentration of C18:0 in the yolk from Groups B, C and D was greater than from Group A $(\mathrm{P}<0.01)$. Yolk from Groups A, E and F had similar concentrations of C18:0. Yolk lipids of the eggs from Groups B, C and D had lower concentrations of C18:1(n-9) compared to Group A (P $<0.01)$. Adding $1.25 \%$ (Group C) or $2.5 \%$ canola oil (Group D) to the diet was not sufficient to maintain the concentrations of C18:1(n-9) and C18:0 in the yolk. The concentrations of C18:2(n-6) in the yolk were similar in all groups. In this study, it was shown that as the proportion of canola oil increased in the diet of layers, the concentrations of $\mathrm{C} 18: 3(\mathrm{n}-3)$ in the yolk increased $(\mathrm{P}<0.01)$. As with $\mathrm{C} 18: 2(\mathrm{n}-6)$, egg yolk from all groups had similar concentrations of C20:4(n-6). Egg yolk from Group A contained no CLA. It was observed that the deposition of c-9, t-11 CLA isomer in the yolks from Groups B, C, D, E and F was about twice that of the t-10, c-12 CLA isomer. Total CLA concentrations (\%) in Groups B, C, D, E and F were $2.38,2.33,1.68,1.36$ and $1.17 \%$, respectively. However, as the level of supplemental canola oil increased in the diet of the hens, accumulation of c-9, t-11 and t-10 c-12 CLA isomers decreased in the egg yolk (P < $0.05)$.

While CLA in a low-fat diet changed the fatty acid composition of the egg yolk, the $\mathrm{pH}$ of the yolk and albumen of the eggs stored at $4{ }^{\circ} \mathrm{C}$ was found to be different from that of the control (Tables 3 and 4). When eggs were stored at $4{ }^{\circ} \mathrm{C}$ for a month, the $\mathrm{pH}$ of yolk from Groups $\mathrm{B}, \mathrm{C}$ and $\mathrm{D}$ increased $(\mathrm{P}<0.01)$ 
compared to Group A. Albumen of the eggs from Groups B, C and D had lower pH values when the eggs were stored at $4{ }^{\circ} \mathrm{C}$ for 30 days compared to the other treatments. Adding $5 \%$ canola oil (Group E) or $10 \%$ canola oil (Group F) completely prevented CLA-induced abnormal changes in the $\mathrm{pH}$ of albumen and yolk in the eggs stored at $4{ }^{\circ} \mathrm{C}$ for 30 days. However, when eggs were stored at room temperature $\left(21-24{ }^{\circ} \mathrm{C}\right)$, yolk $\mathrm{pH}$ or albumen $\mathrm{pH}$ were similar in all groups (Table 5).

Table 2 The fatty acid composition ${ }^{1}(\mathrm{~g} / 100 \mathrm{~g}$ fatty acid methyl esters) of egg yolk from chickens fed diets containing conjugated linoleic acid (CLA) and different levels of canola oil

\begin{tabular}{|c|c|c|c|c|c|c|}
\hline \multirow{2}{*}{ Fatty acids } & \multicolumn{6}{|c|}{ Treatments $^{2}$} \\
\hline & Group A & Group B & Group C & Group D & Group E & Group F \\
\hline $\mathrm{C} 14.0$ & $0.53 \pm 0.0^{\mathrm{a}}$ & $0.45 \pm 0.1^{\mathrm{ab}}$ & $0.52 \pm 0.1^{\mathrm{a}}$ & $0.33 \pm 0.0^{\mathrm{b}}$ & $0.29 \pm 0.0^{\mathrm{b}}$ & $0.27 \pm 0.0^{\mathrm{b}}$ \\
\hline C16:0 & $27.3 \pm 0.3^{b}$ & $35.3 \pm 1.2^{\mathrm{a}}$ & $35.7 \pm 0.9^{\mathrm{a}}$ & $28.5 \pm 0.8^{\mathrm{b}}$ & $26.4 \pm 0.6^{\mathrm{b}}$ & $22.5 \pm 0.1^{\mathrm{c}}$ \\
\hline C16:1(n-7) & $4.7 \pm 0.1^{\mathrm{a}}$ & $1.2 \pm 0.1^{\mathrm{b}}$ & $0.95 \pm 0.1^{\mathrm{bc}}$ & $0.74 \pm 0.0^{\mathrm{cd}}$ & $0.54 \pm 0.1^{\mathrm{d}}$ & $0.35 \pm 0.0^{\mathrm{d}}$ \\
\hline C18:0 & $11.1 \pm 0.3^{\mathrm{c}}$ & $17.4 \pm 0.1^{\mathrm{a}}$ & $16.8 \pm 0.2^{\mathrm{a}}$ & $13.3 \pm 0.4^{\mathrm{b}}$ & $11.0 \pm 0.3^{\mathrm{c}}$ & $10.9 \pm 0.3^{\mathrm{c}}$ \\
\hline C18:1(n-9) & $35.7 \pm 0.1^{b}$ & $22.0 \pm 1.1^{\mathrm{d}}$ & $22.4 \pm 0.1^{\mathrm{d}}$ & $31.5 \pm 0.2^{\mathrm{c}}$ & $36.0 \pm 0.2^{\mathrm{b}}$ & $40.3 \pm 0.5^{\mathrm{a}}$ \\
\hline C18:2(n-6) & $16.6 \pm 0.3$ & $17.2 \pm 0.4$ & $17.9 \pm 0.9$ & $19.1 \pm 0.4$ & $18.6 \pm 0.8$ & $18.3 \pm 0.3$ \\
\hline C18:3(n-3) & $0.23 \pm 0.0^{\mathrm{d}}$ & $0.25 \pm 0.1^{\mathrm{d}}$ & $0.61 \pm 0.1^{\mathrm{c}}$ & $0.70 \pm 0.0^{c}$ & $1.23 \pm 0.0^{\mathrm{b}}$ & $1.58 \pm 0.0^{\mathrm{a}}$ \\
\hline$c-9, \mathrm{t}-11$ & nd & $1.35 \pm 0.08^{\mathrm{a}}$ & $1.29 \pm 0.01^{\mathrm{a}}$ & $1.11 \pm 0.05^{\mathrm{ab}}$ & $0.88 \pm 0.14^{\mathrm{bc}}$ & $0.70 \pm 0.03^{\mathrm{c}}$ \\
\hline $\mathrm{t}-10, \mathrm{c}-12$ & nd & $0.69 \pm 0.1^{\mathrm{a}}$ & $0.60 \pm 0.0^{\mathrm{a}}$ & $0.57 \pm 0.0^{\mathrm{ab}}$ & $0.40 \pm 0.1^{\mathrm{bc}}$ & $0.31 \pm 0.0^{\mathrm{c}}$ \\
\hline$\sum$ CLA & nd & $2.38 \pm 0.3^{\mathrm{a}}$ & $2.33 \pm 0.0^{\mathrm{a}}$ & $1.68 \pm 0.1^{\mathrm{ab}}$ & $1.36 \pm 0.3^{\mathrm{b}}$ & $1.17 \pm 0.1^{\mathrm{b}}$ \\
\hline $\mathrm{C} 20: 4(\mathrm{n}-6)$ & $3.83 \pm 0.2$ & $3.94 \pm 0.6$ & $2.76 \pm 0.4$ & $4.24 \pm 0.2$ & $4.52 \pm 0.6$ & $4.6 \pm 0.0$ \\
\hline$\sum \mathrm{SFA}$ & $38.9 \pm 0.4^{\mathrm{bc}}$ & $53.1 \pm 1.2^{\mathrm{a}}$ & $53.1 \pm 1.1^{\mathrm{a}}$ & $42.1 \pm 0.5^{\mathrm{b}}$ & $37.8 \pm 0.9^{c}$ & $33.7 \pm 0.3^{\mathrm{d}}$ \\
\hline$\sum$ MUFA & $40.4 \pm 0.2^{\mathrm{a}}$ & $23.2 \pm 1.0^{\mathrm{d}}$ & $23.3 \pm 0.1^{\mathrm{d}}$ & $32.2 \pm 0.2^{\mathrm{c}}$ & $36.5 \pm 0.3^{\mathrm{b}}$ & $40.7 \pm 0.5^{\mathrm{a}}$ \\
\hline$\sum$ PUFA & $20.7 \pm 0.4^{\mathrm{b}}$ & $21.4 \pm 0.5^{\mathrm{ab}}$ & $21.3 \pm 1.2^{\mathrm{ab}}$ & $24.0 \pm 0.5^{\mathrm{a}}$ & $24.4 \pm 0.9^{\mathrm{a}}$ & $24.5 \pm 0.3^{\mathrm{a}}$ \\
\hline$\sum \mathrm{UFA}$ & $61.1 \pm 0.4^{\mathrm{b}}$ & $44.6 \pm 1.5^{\mathrm{d}}$ & $44.6 \pm 1.1^{\mathrm{d}}$ & $56.2 \pm 0.4^{\mathrm{c}}$ & $60.9 \pm 0.8^{b}$ & $65.2 \pm 0.3^{\mathrm{a}}$ \\
\hline$n-6 / n-3$ & $89.0 \pm 2.8^{\mathrm{a}}$ & $84.4 \pm 15.9^{\mathrm{a}}$ & $33.9 \pm 6.0^{\mathrm{b}}$ & $33.3 \pm 1.9^{\mathrm{b}}$ & $18.8 \pm 0.4^{\mathrm{c}}$ & $14.5 \pm 0.2^{\mathrm{c}}$ \\
\hline UFA/SFA & $1.57 \pm 0.0^{\mathrm{b}}$ & $0.84 \pm 0.1^{\mathrm{d}}$ & $0.84 \pm 0.0^{\mathrm{d}}$ & $1.34 \pm 0.0^{\mathrm{c}}$ & $1.61 \pm 0.1^{\mathrm{b}}$ & $1.93 \pm 0.0^{\mathrm{a}}$ \\
\hline
\end{tabular}

${ }^{1}$ Values are means \pm s.e. expressed as percentage total fatty acids ( $\mathrm{n}=3$ egg yolk samples per group) and means with different superscripts within a row are different $(\mathrm{P}<0.05)$

${ }^{2}$ Group A - $0.5 \%$ canola oil; Group B - 0.5\% CLA; Group C - $0.5 \%$ CLA plus $1.25 \%$ canola oil; Group D - 0.5\% CLA plus $2.5 \%$ canola oil; Group E - $0.5 \%$ CLA plus $5 \%$ canola oil or Group F - $0.5 \%$ CLA plus $10 \%$ canola oil

$\sum$ SFA - total saturated fatty acids; $\sum$ MUFA - total monounsaturated fatty acids; $\sum$ PUFA - total polyunsaturated fatty acids (excluding CLA); $\sum$ UFA - total unsaturated fatty acids (excluding CLA); nd - not determined

\section{Discussion}

Nutritional studies showed that CLA isomers were readily incorporated into animal tissues depending on their levels in the diet (Ip et al., 1994; Banni et al., 1995; Kramer et al., 1998). It was also found that CLA 
could be incorporated into lipids of liver, muscle, adipose tissue and egg yolk of chickens fed CLA (Aydin, 2000). When CLA was used in a low-fat diet, it was shown to cause higher concentrations of SFA and lower concentrations of MUFA in eggs from chickens (Aydin et al., 2001) and quails (Aydin \& Cook, 2004), possibly by inhibiting the stearoyl-CoA desaturase enzyme. T-10, c-12 CLA isomer is the one causing inhibition of stearoyl-CoA desaturase enzyme (Park et al., 2000). As has been found in other studies (Chamruspollert \& Sell, 1999; Raes et al., 2002; Cherian et al., 2002), in the present study the inclusion of CLA in the diet caused higher concentrations of C16:0 and C18:0 and a lower concentration of C18:1(n-9) in egg yolk. The deposition of c-9, t-11 CLA isomer was also greater than that of the t-10, c-12 CLA isomer, even though concentrations of both CLA isomers were similar in the diets. This result is consistent with the analysis of c-9, t-11 CLA and t-10, c-12 CLA isomers in other studies (Cherian et al., 2002; Badinga et al., 2003; Alvarez et al., 2004). This data suggested that the t-10, c-12 CLA isomer might have a higher catabolic rate than the c-9, t-11 CLA isomer (Park et al., 1999).

Table 3 The effects of dietary treatments on the $\mathrm{pH}^{2}$ of yolk of eggs laid on days 1 to 10 , and stored at $4{ }^{\circ} \mathrm{C}$ for 30 days

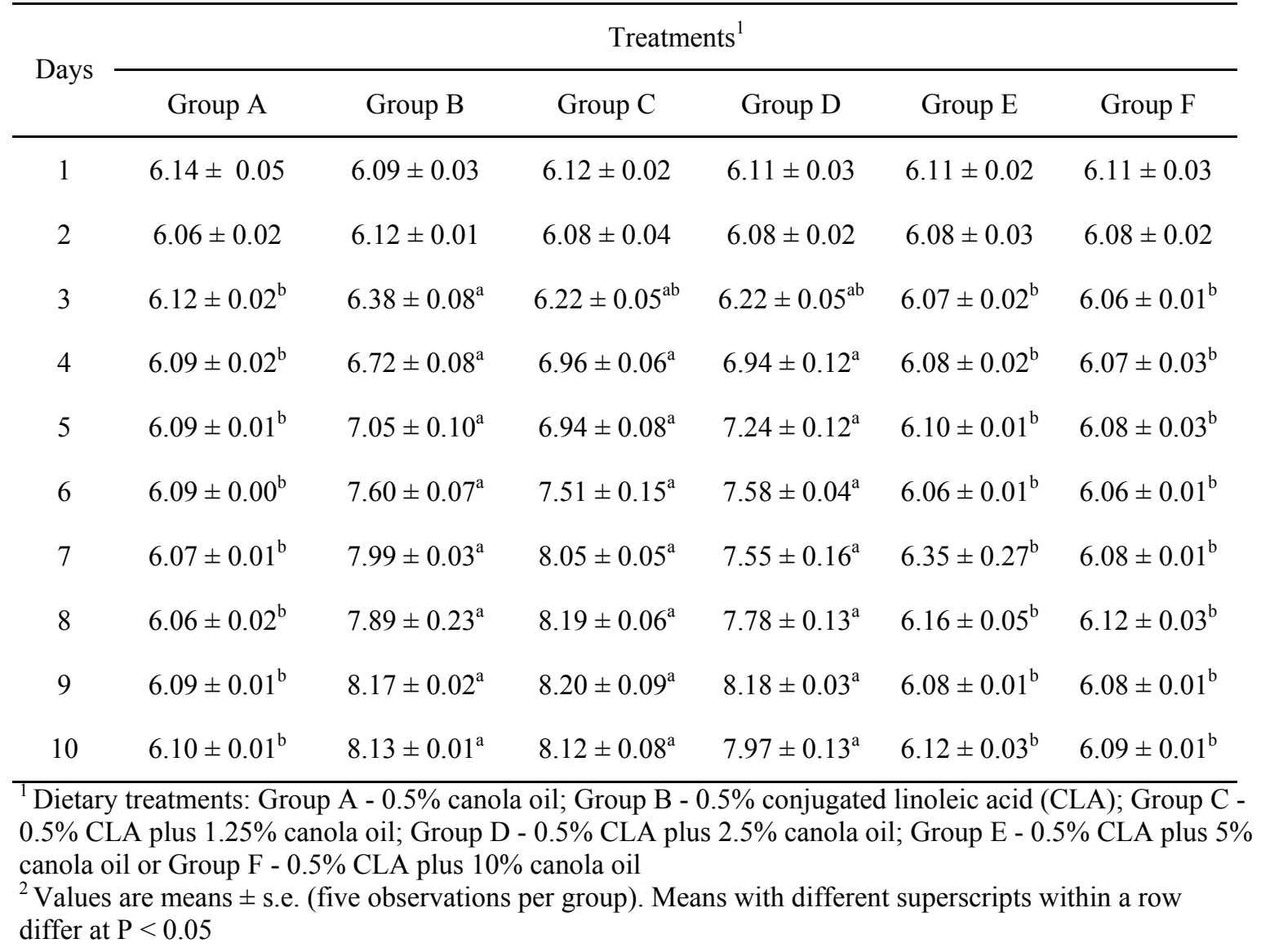

Dietary CLA was shown to cause adverse effects on the quality of eggs stored at cold, but not at warm temperatures (Aydin et al., 2001). When eggs from chickens fed a diet containing 0.5\% CLA (without additional oil) were stored at $4{ }^{\circ} \mathrm{C}$, the texture of yolks was rubbery and yolk and albumen $\mathrm{pH}$ were changed. In addition, eggs from CLA-fed hens had a discoloration in the yolk and albumen when eggs were stored at cold temperatures (Aydin et al., 2001). In the present study, eggs from Group B had a higher viscosity than the others when they were stored at $4{ }^{\circ} \mathrm{C}$ for $30 \mathrm{~d}$ (data not reported here). The mechanism for colour defects of yolks and albumen has yet to be determined. Abo-ashour \& Edwards (1970) suggested that a higher C18:0 content of the egg yolk would probably increase the permeability of the vitelline membrane. It was reported 
that in a cold temperature $\left(4^{\circ} \mathrm{C}\right)$, eggs from CLA-fed hens had higher iron, calcium, and zinc concentrations and lower magnesium, sodium and chloride concentrations in the albumen relative to those from hens fed a control diet (Aydin et al., 2001). It was also shown that 10\% olive oil prevented CLA-related mineral exchange between yolk and albumen, presumably by reducing the yolk SFA which are believed to disrupt the egg yolk vitelline membrane during cold storage.

Table 4 The effects of dietary treatments on the $\mathrm{pH}^{2}$ of albumen of eggs laid on days 1 to 10 , and stored at $4{ }^{\circ} \mathrm{C}$ for 30 days

\begin{tabular}{ccccccc}
\hline \multirow{5}{*}{ Days } & \multicolumn{5}{c}{ Treatments $^{1}$} \\
\cline { 2 - 7 } & Group A & Group B & Group C & Group D & Group E & Group F \\
\hline 1 & $9.00 \pm 0.05$ & $9.06 \pm 0.03$ & $9.08 \pm 0.03$ & $9.10 \pm 0.01$ & $9.08 \pm 0.02$ & $9.04 \pm 0.03$ \\
2 & $9.04 \pm 0.04$ & $9.09 \pm 0.02$ & $9.08 \pm 0.02$ & $9.06 \pm 0.03$ & $9.06 \pm 0.02$ & $9.10 \pm 0.01$ \\
3 & $9.07 \pm 0.01$ & $9.01 \pm 0.02$ & $9.03 \pm 0.02$ & $9.03 \pm 0.02$ & $9.08 \pm 0.01$ & $9.07 \pm 0.01$ \\
4 & $9.00 \pm 0.03^{\mathrm{a}}$ & $8.76 \pm 0.02^{\mathrm{c}}$ & $8.87 \pm 0.01^{\mathrm{b}}$ & $8.85 \pm 0.01^{\mathrm{b}}$ & $8.99 \pm 0.01^{\mathrm{a}}$ & $9.07 \pm 0.01^{\mathrm{a}}$ \\
5 & $8.99 \pm 0.02^{\mathrm{a}}$ & $8.78 \pm 0.05^{\mathrm{b}}$ & $8.82 \pm 0.01^{\mathrm{b}}$ & $8.83 \pm 0.01^{\mathrm{b}}$ & $8.99 \pm 0.03^{\mathrm{a}}$ & $9.03 \pm 0.01^{\mathrm{a}}$ \\
6 & $9.03 \pm 0.02^{\mathrm{a}}$ & $8.66 \pm 0.01^{\mathrm{c}}$ & $8.75 \pm 0.01^{\mathrm{b}}$ & $8.74 \pm 0.01^{\mathrm{b}}$ & $9.04 \pm 0.01^{\mathrm{a}}$ & $9.09 \pm 0.02^{\mathrm{a}}$ \\
7 & $9.07 \pm 0.02^{\mathrm{a}}$ & $8.65 \pm 0.03^{\mathrm{b}}$ & $8.68 \pm 0.02^{\mathrm{b}}$ & $8.69 \pm 0.03^{\mathrm{b}}$ & $8.97 \pm 0.05^{\mathrm{a}}$ & $9.03 \pm 0.01^{\mathrm{a}}$ \\
8 & $9.08 \pm 0.01^{\mathrm{a}}$ & $8.68 \pm 0.02^{\mathrm{c}}$ & $8.66 \pm 0.01^{\mathrm{c}}$ & $8.66 \pm 0.02^{\mathrm{c}}$ & $8.99 \pm 0.02^{\mathrm{b}}$ & $9.05 \pm 0.01^{\mathrm{ab}}$ \\
9 & $9.02 \pm 0.03^{\mathrm{a}}$ & $8.66 \pm 0.01^{\mathrm{b}}$ & $8.73 \pm 0.00^{\mathrm{b}}$ & $8.67 \pm 0.01^{\mathrm{b}}$ & $8.96 \pm 0.06^{\mathrm{a}}$ & $9.08 \pm 0.02^{\mathrm{a}}$ \\
10 & $9.06 \pm 0.01^{\mathrm{a}}$ & $8.65 \pm 0.01^{\mathrm{c}}$ & $8.72 \pm 0.00^{\mathrm{c}}$ & $8.64 \pm 0.01^{\mathrm{c}}$ & $8.98 \pm 0.05^{\mathrm{a}}$ & $9.08 \pm 0.01^{\mathrm{a}}$ \\
\hline
\end{tabular}

Dietary treatments: Group A - $0.5 \%$ canola oil; Group B - $0.5 \%$ conjugated linoleic acid (CLA); Group C - $0.5 \%$ CLA plus $1.25 \%$ canola oil; Group D - $0.5 \%$ CLA plus $2.5 \%$ canola oil; Group E - $0.5 \%$ CLA plus $5 \%$ canola oil or Group F - $0.5 \%$ CLA plus $10 \%$ canola oil

${ }^{2}$ Values are means \pm s.e. (five observations per group). Means with different superscript within a row differ at $\mathrm{P}<0.05$

The $\mathrm{pH}$ of albumen from newly laid eggs ranged between 7.6 and 8.5. During the storage of eggs, the $\mathrm{pH}$ of albumen increased at a temperature dependent rate to a maximum of about 9.7 (Heath, 1977). The rise in the albumen $\mathrm{pH}$ is caused by a loss of carbon dioxide from the egg through the pores in the shell (Heath, 1977). The $\mathrm{pH}$ of yolk in freshly laid eggs is generally about 6 , but during storage, the $\mathrm{pH}$ gradually increases to between 6.4 and 6.9. In the present study, when the shell eggs were stored at $4{ }^{\circ} \mathrm{C}$, egg yolks (laid on days 4-10) from Groups B, C and D had higher $\mathrm{pH}$ values compared to Group A. In the eggs stored at $4{ }^{\circ} \mathrm{C}$ the albumen $\mathrm{pH}$ of Groups $\mathrm{B}, \mathrm{C}$ and $\mathrm{D}$ on days 4-10 of the feeding period were lower than in the other treatments. In the present study it was observed that adding $5 \%$ or $10 \%$ canola oil to the diet completely prevented abnormal $\mathrm{pH}$ changes in yolk and albumen of the eggs stored at $4{ }^{\circ} \mathrm{C}$. In another study, high levels of animal tallow (9.5\%) were reported to maintain the ratio of SFA to MUFA and prevented CLA-related colour changes and $\mathrm{pH}$ changes in yolk and albumen of the eggs stored at cold temperatures (Aydin \& Cook, 2005). When eggs were stored at room temperature, no discoloration occurred in the yolk or albumen. Also, when fresh eggs were separated into yolk and albumen and stored at $4{ }^{\circ} \mathrm{C}$ for one month, no colour changes were observed in the yolk or the albumen (R. Aydin, unpublished observation). This unpublished observation suggested that the discoloration of yolk and albumen of the whole eggs stored at a 
cold temperature might be associated with the increased permeability of the vitelline membrane due to altered fatty acid composition such that minerals can move down their concentration gradient (Aydin et al., 2001).

Table 5 The effects of dietary treatments on the $\mathrm{pH}^{2}$ of albumen and yolk of the eggs stored at room temperature for 30 days

\begin{tabular}{ccc}
\hline & \multicolumn{2}{c}{ pH value } \\
\hline Treatments & & \\
\cline { 2 - 3 } & Egg yolk & Egg albumen \\
\hline Group A & $6.36 \pm 0.09$ & $9.33 \pm 0.01$ \\
Group B & $6.31 \pm 0.08$ & $9.34 \pm 0.01$ \\
Group C & $6.25 \pm 0.02$ & $9.32 \pm 0.01$ \\
Group D & $6.28 \pm 0.03$ & $9.30 \pm 0.02$ \\
Group E & $6.42 \pm 0.02$ & $9.28 \pm 0.01$ \\
Group F & $6.39 \pm 0.01$ & $9.30 \pm 0.02$ \\
\hline
\end{tabular}

\footnotetext{
${ }^{1}$ Dietary treatments: Group A - 0.5\% canola oil; Group B - 0.5\% conjugated linoleic acid (CLA); Group C - $0.5 \%$ CLA plus $1.25 \%$ canola oil; Group D - $0.5 \%$ CLA plus $2.5 \%$ canola oil; Group E - $0.5 \%$ CLA plus $5 \%$ canola oil or Group F - 0.5\% CLA plus $10 \%$ canola oil

${ }^{2}$ Values are means \pm s.e. (five observations per group). Means with different superscript letters within a column differ at the level of $\mathrm{P}<0.05$
}

However, since high levels of vegetable oil or animal fats prevented CLA-induced undesirable colour and $\mathrm{pH}$ changes in the yolk and albumen of the eggs stored at cold temperatures, they also caused a decrease in the concentration of egg CLA isomers as well as total CLA concentrations (Aydin et al., 2001; Aydin \& Cook, 2005). In the present study, the lowest level of canola oil required to prevent CLA-induced changes on egg quality was $5 \%$. When canola was added at levels of $5 \%$ or $10 \%$, the concentration of total CLA oil (c-9, t-11 and t-10, c-12 CLA isomers) decreased by about 1.7 or 2-fold, respectively, compared to Group B (Table 2).

\section{Conclusion}

This study showed the adding of $5 \%$ or $10 \%$ canola completely prevented CLA-related colour changes and $\mathrm{pH}$ changes in egg yolk by maintaining the ratio of UFA to SFA and led to increased concentrations of both CLA isomers and C18:3(n-3) in the yolk. Therefore, an egg yolk could be enriched with both CLA and n-3 fatty acids for the development of new designer eggs for human nutrition.

\section{References}

Abo-ashour, A.M. \& Edwards, H.M., 1970. Effect of dietary sterculia foetida oil on pink-white discoloration and fatty acid distribution in stored eggs. J. Nutr. 100, 757-766.

Alvarez, C., Cachaldora, P., Mendez, J., Garcia-Rebollar, P. \& De Blas, J.C., 2004. Effects of dietary conjugated linoleic acid and fish oil supplementation on performance and egg quality in laying hens. Br. Poult. Sci. 45, 524-529.

Aydin, R., 2000. The effects of dietary conjugated linoleic acid on avian lipid metabolism. Ph.D. thesis. University of Wisconsin, Madison.

Aydin, R. \& Cook, M.E., 2004. The effect of dietary conjugated linoleic acid on egg yolk fatty acids and hatchability in Japanese quail. Poult. Sci. 83, 2016-2022. 
Aydin, R. \& Cook, M.E., 2005. The influence of conjugated linoleic acid enriched tallow on egg hatchability and quality in chicken. Int. Poult. Sci. 4(8), 536-542.

Aydin, R., Pariza, M.W. \& Cook, M.E., 2001. Olive oil prevents the adverse effects of dietary conjugated linoleic acid on chick hatchability and egg quality. J. Nutr. 131, 800-806.

Badinga, L., Selberg, K.T., Dinges, A.C., Comer, C.W. \& Miles, R.D., 2003. Dietary conjugated linoleic acid alters hepatic lipid content and fatty acid composition in broiler chickens. Poult. Sci. 82, 111-116.

Banni, S. \& Martin, J.C., 1998. Conjugated linoleic acid and metabolites. In: Trans Fatty Acids in Human Nutrition. Eds. Sebedio, J.L. \& Christie, W.W., The Oily Press Ltd., Dundee, Scotland. pp. 261-302.

Banni, S., Day, B.W., Evans, R.W., Corongiu, F.P. \& Lombardi, B., 1995. Detection of conjugated diene isomers of linoleic acid in liver lipids of rats fed a choline-devoid diet indicates that the diet does not cause lipoperoxidation. J. Nutr. Biochem. 6, 281-289.

Blankson, H., Stakkestad, J.A., Fagertun, H., Thom, E., Wadstein, J. \& Gudmundsen, O., 2000. Conjugated linoleic acid reduces body fat mass in overweight and obese humans. J. Nutr. 130, 2943-2948.

Chamruspollert, M. \& Sell, J.L., 1999. Transfer of dietary conjugated linoleic acid to egg yolks of chickens. Poult. Sci. 78, 1138-1150.

Cherian, G., Goeger, M.P. \& Ahn, D.U., 2002. Dietary conjugated linoleic acid with fish oil alters yolk n-3 and trans fatty acid content and volatile compounds in raw, cooked and irradiated eggs. Poult. Sci. 81, 1571-1577.

Chin, S.F., Liu, W., Storkson, J.M., Ha, Y.L. \& Pariza, M.W., 1992. Dietary sources of conjugated dienoic isomers of linoleic acid, a newly recognized class of anticarcinogens. J. Food Compos. Anal. 5, 185197.

Cook, M.E., Miller, C.C., Park, Y. \& Pariza, M.W., 1993. Immune modulation by altered nutrient metabolism: Nutritional control of immune-induced growth depression. Poult. Sci. 72, 1301-1305.

Corl, B.A., Barbano, D.M., Bauman, D.E. \& Ip, C., 2003. Cis-9 trans-11 CLA derived endogenously from trans-11 18:1 reduces cancer risk in rats. J. Nutr. 133, 2893-2900.

Decker, E.A., 1995. The role of phenolics, conjugated linoleic acid, carnosine, and pyrroloquinoline quinone as nonessential dietary antioxidants. Nutr. Rev. 53, 49-58.

Du, M., Ahn, D.U. \& Sell, J.L., 1999. Effect of dietary conjugated linoleic acid on the composition of egg yolk lipids. Poult. Sci. 78, 1639-1645.

Folch, J., Lees, M. \& Sloane-Stanley, G.H., 1957. A simple method for the isolation and purification of total lipids from animal tissues. J. Biol. Chem. 226, 497-509.

Franklin, S.T., Martin, K.R., Baer, R.J., Schingoethe, D.J. \& Hippen, A.R., 1999. Dietary marine algae (Schizochytrium sp.) increases concentrations of conjugated linoleic acid, docosahexaenoic and trans vaccenic acids in milk of dairy cows. J. Nutr. 129, 2048-2052.

Heath, J.L., 1977. Chemical and related osmotic changes in egg albumen during storage. Poult. Sci. 56, 822828.

Ip, C., Singh, M., Thompson, H.J. \& Scimeca, J.A., 1994. Conjugated linoleic acid suppresses mammary carcinogenesis and proliferative activity of the mammary gland in the rat. Cancer Res. 54, 1212-1215.

Jones, S., Ma, D.W.L., Robinson, F.E., Field, C.J. \& Clandinin, M.T., 2000. Isomers of conjugated linoleic acid (CLA) are incorporated into egg yolk lipids by CLA-fed laying hens. J. Nutr. 130, 2002-2005.

Kramer, J.K., Sehat, G.N., Dugan, M.E.R., Mossoba, M.M., Yurawecz, M.P., Roach, J.A.G., Eulitz, K., Aalhus, J.L., Schaefer, A.L. \& Ku, Y., 1998. Distributions of conjugated linoleic acid (CLA) isomers in tissue lipid classes of pigs fed a commercial CLA mixture determined by gas chromatography and silver ion-high performance liquid chromatography. Lipids 33, 549-558.

Park, Y., Albright, K.J., Storkson, J.M., Liu, W., Cook, M.E. \& Pariza, M.W., 1999. Changes in body composition during feeding and withdrawal of dietary conjugated linoleic acid. Lipids 34, 243-248.

Park, Y., Storkson, J.M., Ntambi, J.M., Cook, M.E., Sih, C.J. \& Pariza, M.W., 2000. Inhibition of hepatic stearoyl-CoA desaturase activity by trans-10, cis-12 conjugated linoleic acid and its derivatives. Biochim. Bioph. Acta 1486, 285-292.

Raes, K., Huyghebaert, G., Smet, S.D., Nollet, L., Arnouts, S. \& Demeyer, D., 2002. The deposition of conjugated linoleic acids in eggs of laying hens fed diets varying in fat level and fatty acid profile. J. Nutr. 132, 182-189. 